\title{
Correction to: Improvements in Skeletal Muscle Can Be Detected Using Broadband NIRS in First-Time Marathon Runners
}

Siana Jones, Matthew Kinsella, Camilla Torlasco, Pardis Kaynezhad, Isabel de Roever, James C. Moon, Alun D. Hughes, and Gemma Bale

\section{Correction to:}

Chapter 31 in: P.-D. Ryu et al. (eds.), Oxygen Transport to Tissue XLI, Advances in Experimental Medicine and Biology 1232, https://doi.org/10.1007/978-3-030-34461-0_31

This chapter was inadvertently published as an open access chapter. However, the open access for this chapter has now been reverted. 